\title{
Enhancing the efficacy of climate change litigation: how to resolve the 'fair share question' in the context of international human rights law
}

\author{
Gerry Liston* \\ National University of Ireland, Galway, Ireland
}

The ambiguity surrounding what constitutes a State's fair share of the global burden of mitigating climate change has undermined the ability of domestic climate change litigation to bring about emissions reductions which are collectively capable of meeting the goal of the Paris Agreement. When confronted with challenges to the adequacy of States' mitigation efforts, domestic courts have also drawn on States' international human rights law obligations. This paper argues that when applying these obligations, the uncertainty surrounding the fair share question must be resolved so as to ensure individual mitigation obligations which are collectively consistent with the Paris Agreement. The analysis focuses on the obligations under the European Convention on Human Rights and outlines how general principles of law applicable in situations involving causal uncertainty could be invoked to address the fair share question.

Keywords: climate change litigation, States' fair share, international human rights, causal uncertainty, shared responsibility

\section{INTRODUCTION}

In November 2019, over 11,000 scientists declared 'clearly and unequivocally that planet Earth is facing a climate emergency'. ${ }^{1}$ Around the same time, a number of leading climate scientists warned that an increase in the global average temperature beyond the $1.5^{\circ} \mathrm{C}$ target enshrined in Article 2 of the Paris Agreement ${ }^{2}$ (the $1.5^{\circ} \mathrm{C}$ target) would pose 'an existential threat to civilization'. ${ }^{3}$ With the planet currently on course to warm

* Legal Officer with the Global Legal Action Network, PhD candidate at the Irish Centre for Human Rights, National University of Ireland, Galway and Solicitor (Ireland). I am very grateful to Dr Ekaterina Yahyaoui Krivenko, Kevin Liston, Dr Gearóid Ó Cuinn and Dr Tom Sparks for their comments on a previous draft of this article. I am equally grateful to Paul Clark, Richard Reynolds and Marc Willers QC of Garden Court Chambers for their comments. Any errors remain entirely my own.

1. William J Ripple, Christopher Wolf, Thomas M Newsome et al, 'World Scientists' Warning of a Climate Emergency' (2020) 70(1) Bioscience 8, 8.

2. Paris Agreement to the United Nations Framework Convention on Climate Change (adopted 12 December 2015, entered into force 4 November 2016) XXVII UNTS 7.d (Paris Agreement).

3. Timothy M Lenton, Johan Rockström, Owen Gaffney et al, 'Climate Tipping Points - Too Risky to Bet Against' (2019) 575 Nature 592, 595. 
by $3.5^{\circ} \mathrm{C}$ by $2100,{ }^{4}$ it is no wonder that the UN High Commissioner for Human Rights, Michelle Bachelet, has stated that ' $[\mathrm{t}]$ he world has never seen a threat to human rights of this scope'. ${ }^{5}$ And yet the latest reports indicate that the levels of global greenhouse gas emissions responsible for this unprecedented threat continue to reach record highs. ${ }^{6}$ Against this background, lawyers and climate activists are joining forces with increasing frequency in seeking to hold States accountable for shortcomings in their efforts to reduce their greenhouse gas emissions (mitigation efforts). ${ }^{7}$ The main success to emerge from this movement is the Dutch Urgenda case which resulted in the Dutch government being ordered to strengthen its mitigation efforts. ${ }^{8}$ Concerningly, however, a significant number of similar cases brought in other countries have been dismissed.

One issue which has emerged as posing a significant obstacle to domestic cases succeeding is the ambiguity surrounding what constitutes a State's fair share of the global burden of mitigating climate change (the fair share question). To date, the fair share question has combined with the (perhaps predictable) exercise of judicial restraint in the assessment of government policy to undermine the potential for climate change litigation to force governments to adopt the far-reaching mitigation efforts that are urgently needed. Indeed, even in the Urgenda case these factors caused the Dutch courts to adopt an approach which, if replicated globally, would fail to ensure that global warming is kept to the $2{ }^{\circ} \mathrm{C}$ global warming target on which that decision is based. At the same time, as will be seen, these cases make clear that domestic courts draw significantly on (their understanding of) States' international obligations relating to the mitigation of climate change when determining their obligations under domestic law.

This article outlines how general principles of law applicable in situations involving causal uncertainty which stem from the involvement of multiple wrongdoers can be invoked to address the difficulty created by the fair share question. Specifically, it addresses how these principles can be applied in relation to the positive obligations arising under international human rights law (IHRL) to prevent harm from climate change. Particular focus is placed on the European Convention on Human Rights ${ }^{9}$ on the basis that the obligations under this treaty have featured prominently in the decisions in climate change cases throughout Europe. It is also important to note that this article is written in the context of the imminent filing, on behalf of a group of Portuguese children

4. United Nations Environment Programme, 'Emissions Gap Report 2019' (November 2019)

$27<$ https://wedocs.unep.org/bitstream/handle/20.500.11822/30797/EGR2019.pdf > accessed 18 May 2020.

5. Office of the UN High Commissioner for Human Rights, 'Global Update at the 42nd Session of the Human Rights Council. Opening Statement by UN High Commissioner for Human Rights Michelle Bachelet' (9 September 2019) <https://www.ohchr.org/EN/ NewsEvents/Pages/DisplayNews.aspx?NewsID=24956\&;LangID=E $>$ accessed 18 May 2020.

6. World Meteorological Organization, 'Greenhouse Gas Concentrations in Atmosphere Reach Yet Another High' (25 November 2019) <https://public.wmo.int/en/media/pressrelease/greenhouse-gas-concentrations-atmosphere-reach-yet-another-high> accessed 18 May 2020.

7. For a comprehensive database of climate change litigation worldwide see Sabin Center for Climate Change Law, 'Climate Change Litigation Databases' <www.climatecasechart.com> accessed 18 May 2020 (SCCCL Database).

8. The State of the Netherlands (Ministry of Economic Affairs and Climate Policy) v Stichting Urgenda (Urgenda) [2019] Dutch Supreme Court 19/00135 (Engels).

9. European Convention for the Protection of Human Rights and Fundamental Freedoms, as amended by Protocols Nos 11 and 14 [1950] ETS 5 (ECHR). 
and young adults, of a case with the European Court of Human Rights (ECtHR) against multiple States Parties to the Convention in relation to the risk of harm which their continued contributions to global emissions pose to the youth applicants' ECHR-protected rights.

The article is structured as follows. Section 2 provides an overview of the source of the ambiguity surrounding the fair share question and how, combined with a tendency to exercise judicial restraint in this area, it has undermined the efficacy of domestic climate change litigation. Section 3 then examines the recently adopted Guiding Principles on Shared Responsibility in International Law (the Guiding Principles on Shared Responsibility ${ }^{10}$ which apply to situations involving the contribution by multiple States to 'indivisible injury' and in particular the distinction between shared responsibility for a single wrongful act and for multiple wrongful acts. As will be seen, this distinction is of relevance to how the fair share question ought to be addressed in the context of the IHRL obligation to prevent harm from climate change. Section 4 considers how principles of domestic law which operate in relation to situations involving causal uncertainty and multiple wrongdoers can be applied to address the fair share question in the context of the relevant ECHR obligations. A brief conclusion is then provided in Section 5.

\section{THE FAIR SHARE QUESTION, JUDICIAL RESTRAINT AND DOMESTIC CLIMATE CHANGE LITIGATION}

In any legal challenge to the adequacy of a State's mitigation efforts based on the impacts which climate change stands to cause, the fair share question invariably arises as an issue. ${ }^{11}$ The reason this is the case is that there exists (and has existed) a global 'carbon budget' which can be exploited while still keeping global warming to the $1.5^{\circ} \mathrm{C}$ target. ${ }^{12}$ It cannot therefore be said that any contribution which a State has made or will make to global emissions is unlawful. Determining the point at which such a contribution becomes unlawful, however, inescapably involves consideration of States' equitable share of the global carbon budget. This, as Benoit Mayer notes, is a question which 'courts may lack the legitimacy to [resolve]'. ${ }^{13} \mathrm{He}$ also observes in this context that ' $[\mathrm{t}] \mathrm{he}$ task of lawyers would be easier if the global mitigation objective was an immediate and absolute cessation of all [greenhouse gas] emissions'. ${ }^{14}$ Clearly this task would also be made easier if the Paris Agreement contained a set of burdensharing principles from which it would be possible to extrapolate emissions reduction targets for individual States which, when aggregated, would result in total reductions consistent with the $1.5^{\circ} \mathrm{C}$ target. That Agreement, however, takes the opposite approach.

10. André Nollkaemper, Jean d'Aspremont, Christiane Ahlborn et al, 'Guiding Principles on Shared Responsibility in International Law' (2020) 31(1) European Journal of International Law 15 (Guiding Principles on Shared Responsibility).

11. See Benoit Mayer, 'Interpreting States' General Obligations on Climate Change Mitigation: A Methodological Review' (2019) 28(2) Review of European, Comparative and International Environmental Law 107; Donald A Brown, 'Using the Paris Agreement's Ambition Ratcheting Mechanisms to Expose Insufficient Protection of Human Rights in Formulating National Climate Policies' in Sébastien Duyck, Sébastien Jodoin and Alyssa Johl (eds), Routledge Handbook of Human Rights and Climate Governance (Routledge, Abingdon 2018) 222.

12. Brown (n 11) 225-228.

13. Mayer (n 11) 115.

14. Ibid 112. 
As Jacqueline Peel and Philippe Sands note, '[r]ather than targets and timetables for emissions reductions enshrined in international law, the hallmark of the Paris Agreement is its "bottom-up approach", with the scope of mitigation and adaptation actions to be determined by individual parties according to their domestic political and economic priorities'. ${ }^{15}$

Central to this bottom-up approach is the obligation on State Parties to 'prepare, communicate and maintain successive nationally determined contributions [NDCs] that it intends to achieve'. ${ }^{16}$ These successive NDCs must furthermore 'represent a progression beyond the Party's then current nationally determined contribution and reflect its highest possible ambition, reflecting its common but differentiated responsibilities and respective capabilities, in the light of different national circumstances'. ${ }^{17}$ There is also an expectation that developed countries 'should continue taking the lead by undertaking economy-wide absolute emission reduction targets'. ${ }^{18}$ Importantly, however, the meaning of the central principle of 'common but differentiated responsibilities and respective capabilities, in the light of different national circumstances' on which these mitigation obligations rest is vague and heavily contested. ${ }^{19}$ In other words, there is no agreement as to the extent to which they require a State's mitigation burden to be determined according to its historical contribution to global emissions, its capacity to mitigate, on the basis of its emissions per capita or otherwise. ${ }^{20}$ That indeed is a central feature of the bottom-up approach. As Lavanya Rajamani notes, '[i]n the context of such divergences on the principle, the expectation that the Agreement will be implemented to reflect this principle essentially leaves the choice of interpretation, and degree of implementation, to national determination' ${ }^{21}$ The predictable consequence of leaving States this choice is, of course, that each State 'will adopt an approach that favours its own interest [which in turn] will result in insufficient overall mitigation'. ${ }^{22}$

15. Jacqueline Peel and Philippe Sands, Principles of International Environmental Law (4th edn, CUP, Cambridge 2018) 300. On the Paris Agreement see Daniel Klein, Maria Pia Carazo, Meinhard Doelle et al (eds), The Paris Agreement on Climate Change: Analysis and Commentary (OUP, Oxford 2017); Daniel Bodansky, Jutta Brunnée and Lavanya Rajamani, International Climate Change Law (OUP, Oxford 2017).

16. Paris Agreement (n 2) art 4(2).

17. Ibid art 4(3).

18. Ibid art 4(4).

19. On the meaning and contested nature of this concept see Lavanya Rajamani, 'Ambition and Differentiation in the 2015 Paris Agreement: Interpretative Possibilities and Underlying Politics' (2016) 65 International and Comparative Law Quarterly 493; Jutta Brunnée and Charlotte Streck, 'The UNFCCC as a Negotiation Forum: Towards Common but More Differentiated Responsibilities' (2013) 13(5) Climate Policy 589; Peel and Sands (n 15) 244-248; Christopher D Stone, 'Common but Differentiated Responsibilities in International Law' (2004) 98(2) American Journal of International Law 276.

20. For an overview of the various approaches to burden-sharing see Marc Fleurbaey, Sivan Kartha, Simon Bolwig et al, 'Sustainable Development and Equity' in Ottmar Edenhofer, Ramón Pichs-Madruga, Youba Sokona et al (eds), Climate Change 2014: Mitigation of Climate Change - Contribution of Working Group III to the Fifth Assessment Report of the Intergovernmental Panel on Climate Change (CUP, Cambridge 2014) 317-319.

21. Lavanya Rajamani, 'Guiding Principles and General Obligation (Article 2.2 and Article 3)' in Klein et al (n 15) 134.

22. Tim Crosland, Aubrey Meyer and Margaretha Wewerinke-Singh, 'The Paris Agreement Implementation Blueprint: A Practical Guide to Bridging the Gap Between Actions and Goal and Closing the Accountability Deficit (Part 1)' (2016) 24(3-4) Environmental Liability: Law, Policy and Practice 114, 117. 


\subsection{The Paris Agreement's bottom-up approach and judicial restraint in domestic climate change litigation: a brief overview}

A brief overview of a selection of domestic climate change cases serves to illustrate how the bottom-up approach of the Paris Agreement and judicial reluctance to intervene in the area of policymaking have combined to undermine the efficacy of climate change litigation. Starting with the UK, the High Court of England and Wales dismissed a challenge brought to the refusal by the UK government to revise the 2050 carbon target provided for under the UK's Climate Change Act $2008 .^{23}$ The applicants argued that this refusal frustrated the purpose of the Act because the existing target was not sufficient to meet the ambition of the Paris Agreement to which it was intended to give effect. The court held, however, that this argument 'rest[ed] on an incorrect interpretation of the terms and implications of the Paris Agreement', ${ }^{24}$ having noted previously that the Agreement 'does not impose a binding legal target on each specific contracting party to achieve any specified temperature level by $2050{ }^{\prime}{ }^{25}$ The court also dismissed a separate argument that the refusal to amend the target in question amounted to a breach of the State's positive obligation under Articles 2 (right to life) and 8 (right to respect for private and family life and one's home) of the ECHR to prevent harm to the applicants from climate change, noting that 'this is an area where the executive has a wide discretion to assess the advantages and disadvantages of any particular course of action'. ${ }^{26}$ In Ireland, an almost identical approach to the same ECHR Articles was adopted by the High Court of Ireland in a case involving a challenge to the Irish Government's climate change mitigation policies. ${ }^{27}$

More recently, a challenge to German mitigation efforts was rejected on similar grounds by the Administrative Court of Berlin. ${ }^{28}$ The court held that while climate policy must be consistent with the obligation to protect fundamental rights under the German Constitution, the government enjoys broad discretion in this area such that the measures in question would need to be proven to be wholly inadequate to be found to be unconstitutional. ${ }^{29}$ It concluded that this was not the case in part by reference to the fact that Germany's emissions reduction target was more ambitious than both the target adopted by the European Union (EU) and that endorsed in the Urgenda case, discussed below. ${ }^{30}$ While it acknowledged the appeal of distributing the remaining global carbon budget on a per capita basis, as contended by the applicants, it noted that the question of the equitable distribution of the global carbon budget involved ethical considerations the subject of ongoing political negotiation. ${ }^{31}$ It therefore declined to adopt this understanding of equity as a mandatory legal minimum under German law. Regarding Germany's positive obligation under Article 2 of the ECHR, the court held that the impugned policies were

23. Plan B v Secretary of State for Business, Energy and Industrial Strategy [2018] EWHC 1892 (Admin), [2019] Environmental Law Reports 13.

24. Ibid [39].

25. Ibid [30].

26. Ibid [49].

27. Friends of the IrishâEnvironment CLG v Ireland [2019] IEHC 747, [2019] 9 JIC 1901 [143]-[144]. On appeal, the Irish Supreme Court did not address the substantive ECHR points raised in the case as it held that the applicant lacked standing to maintain a claim under the Convention. See Friends of the Irish Environment CLG v Ireland [2020] IESC 49 [7.23]-[7.24].

28. Family Farmers and Greenpeace Germany v Germany [2018] VG 10 K 412.18.

29. Ibid [77]-[78].

30. Ibid [82].

31. Ibid [83]. 
compatible with the Convention, referring to the wide 'margin of appreciation' enjoyed by States under the Convention and, further, that such obligations must not impose an impossible or disproportionate burden on the State. ${ }^{32}$

A further illustration is provided by the decision of the Norwegian Court of Appeal concerning a challenge to the issuing of licences for the extraction of significant quantities of oil and gas in the Barents Sea. ${ }^{33}$ There it was alleged that the decision to issue these licences was incompatible with both the right to a healthy environment under the Norwegian Constitution and the State's obligations under Articles 2 and 8 of the ECHR. The court held that the discretionary margin enjoyed by the government was the same under both the Norwegian Constitution and the ECHR. ${ }^{34}$ In determining the scope of that margin, it noted that combined current NDCs are inconsistent with the goal of the Paris Agreement and that the 'burden-sharing principles in the Agreement are suited to strengthening Norway's responsibility'. ${ }^{35}$ The court noted, however, that even a global emissions reduction in line with the $1.5^{\circ} \mathrm{C}$ target provided 'room' for some emissions. ${ }^{36}$ It went on to conclude that the socio-economic and political considerations associated with the licensing of oil and gas extraction required the courts to exercise restraint in this area and held that the government had not exceeded its discretion. ${ }^{37}$

A final example of note is the decision of the High Court of New Zealand, ${ }^{38}$ which though evidently not concerned with the ECHR, provides perhaps the strongest example of a domestic court relying on the Paris Agreement's bottom-up approach in dismissing a challenge to the adequacy of a country's mitigation target. Thus, the court noted that the Paris Agreement requires that States adopt mitigation efforts which reflect their 'highest possible ambition' and that developed countries take the lead in this area but that it ultimately 'leaves these matters to be nationally determined'. ${ }^{39}$ There was, furthermore, according to the court, 'no requirement for countries to adopt a target that if adopted by all would achieve warming well below $2^{\circ} \mathrm{C}$, nor to alter its NDC because the combined [NDCs] were insufficient to meet the target' ${ }^{40}$ Mirroring the approach of the Berlin Administrative Court, the court further held that '[o]ther countries' targets were relevant to test the fairness and ambition of our target' and that ' $t \mathrm{t}$ ] $\mathrm{he}$ evidence shows that our target is fair when considered on this [comparative] basis' ${ }^{41}$

\subsection{The Urgenda decision}

As with each of the cases bar the case from New Zealand referred to above, the Urgenda case involved a challenge to the adequacy of the Netherlands' mitigation efforts in part

32. Ibid [84] citing Kolyadenko and Others $v$ Russia App No 17423/05 (ECtHR, 28 February 2012) [160].

33. Greenpeace Nordic Association v Ministry of Petroleum and Energy 18-060499ASDBORG/03.

34. Ibid [36].

35. Ibid [27].

36. Ibid [29].

37. Ibid [31].

38. Thomson $v$ The Minister for Climate Change Issues [2017] NZHC 733, [2018] 2 NZLR 160.

39. Ibid [139].

40. Ibid [159].

41. Ibid [165]-[166]. 
on grounds that they were incompatible with its positive obligations under Articles 2 and 8 of the ECHR. ${ }^{42}$ The court held that these obligations required the Netherlands to adopt mitigation efforts to protect Dutch residents from harm caused by climate change. ${ }^{43}$ It also noted with regard to the positive obligations arising under the ECHR that while 'states do have discretion in choosing the steps to be taken ... these must actually be reasonable and suitable'. ${ }^{44}$ However, as held by the Berlin Administrative Court, it held that the obligations in question could not be interpreted as imposing an 'impossible or disproportionate burden' on the State. ${ }^{45}$ Regarding the fact that Dutch emissions make a relatively minor contribution to global emissions, the court referred to Article 47 of the International Law Commission's (ILC) Articles on the Responsibility of States for Internationally Wrongful Acts (ARSIWA) ${ }^{46}$ concerning the responsibility of a plurality of States for the same internationally wrongful act (discussed below) to support its view that States are both jointly responsible and 'partially responsible on an individual basis' for climate change and its consequences. ${ }^{47}$ The fact that ' $[\mathrm{m}]$ any countries have corresponding rules in their liability law system' further supported this conclusion. ${ }^{48}$

As regards the Netherlands' fair share of global emissions reductions, this was 'in principle, a matter for the government and parliament' ${ }^{49}$ However, 'the courts can assess whether the measures taken by the State are too little in view of what is clearly the lower limit of its share'. ${ }^{50}$ Central to this assessment were the 'clear views, agreements and/or consensus in an international context about the distribution of measures among countries'. ${ }^{1}$ This in turn stemmed from the principle that the ECHR must be interpreted in light of the norms of both domestic and international law on which there is 'common ground' among the majority of the Council of Europe Member States. ${ }^{52}$ The court held, however, that '[i]n determining the State's minimum obligations, the courts must observe restraint' such that it is 'only in clear-cut cases that the courts can rule ... that the State has a legal obligation to take measures'. ${ }^{53}$

The court then turned to the range of reductions ( 25 per cent to 40 per cent on 1990 levels by 2020) which the applicants had argued provided a measure for the minimum mitigation effort permitted by Dutch law. It observed that the parties to the Kyoto Protocol to the UN Framework Convention on Climate Change, ${ }^{54}$

42. Urgenda (n 8).

43. Ibid [5.6.2].

44. Ibid [5.3.2], citing, in relation to art 2, Budayeva and Others v Russia App No 15339/02 (ECtHR, 20 March 2008) [134], Brincat and Others v Malta App No 60908/11 (ECtHR, 24 July 2014) [101], and, in relation to art 8, Fadeyeva v Russia App No 55723/00 (ECtHR, 9 June 2005) [96].

45. Ibid [5.3.4,] citing Budayeva (n 44) para 135 and Brincat (n 44) para 101.

46. ILC, 'Articles on the Responsibility of States for Internationally Wrongful Acts, with Commentaries' (2001) Yearbook of the International Law Commission 2001/II(2).

47. Urgenda (n 8) [5.7.6].

48. Ibid.

49. Ibid [6.3].

50. Ibid.

51. Ibid.

52. Ibid. See also [5.4.2] citing Demir and Baykara v Turkey App No 34503/97 (ECtHR, 12 November 2008) [85]-[86].

53. Ibid [6.6].

54. United Nations Framework Convention on Climate Change (adopted 9 May 1992, entered into force 21 March 1994) XXVII UNTS 7 (UNFCCC); Kyoto Protocol to the UNFCCC (adopted 11 December 1997, entered into force 16 February 2005) 2303 UNTS 162 (Kyoto Protocol). 
which included the Netherlands, had agreed on several occasions that the countries listed in Annex I to that Convention (broadly corresponding with developed countries) ought to reduce their emissions according to this range in order to prevent climate change from exceeding $2^{\circ} \mathrm{C} .{ }^{55}$ This, among other factors, demonstrated 'a high degree of international consensus on the urgent need for the Annex I countries to reduce greenhouse emissions by at least $25-40$ per cent by 2020 compared to 1990 levels' which could be 'regarded as common ground' for the purpose of the relevant ECHR jurisprudence. ${ }^{56}$ A reduction of 25 per cent on 1990 levels by 2020 (an increase of 5 percentage points relative to the government's target for that year) could 'therefore be regarded as an absolute minimum' for the purpose of the State's obligations under Articles 2 and $8 .^{57}$

The decision in Urgenda has rightly been celebrated as setting a major precedent with global significance. ${ }^{58}$ According to Patrícia Ferreira, referring to the first instance decision which was upheld by the Supreme Court, it proves that, 'despite the vague nature of the concept "to take the lead" in the climate regime, this core aspect of differentiation [between developed and developing countries] may have sufficient persuasive force to be used as a complementary tool in the interpretation of national obligations'. ${ }^{59}$ It is, at the same time, important to highlight that if every country were to reduce their emissions by the lowest amounts in the range considered in Urgenda, this would be insufficient to achieve the global temperature target to which that range is linked. As Yann Robiou du Pont and Malte Meinshausen have stated in relation to this decision, 'systematic court decisions that governments must follow the least-ambitious end of an equity range would be insufficient to achieve the [goal of the] Paris Agreement'. ${ }^{0}$ This weakness is compounded by the fact that developing countries already viewed the equity range considered in Urgenda with 'scepticism and outright hostility'. ${ }^{61}$ This means, of course, that if domestic courts in developing countries were to follow the approach adopted in Urgenda, they could not even require their governments to reduce their emissions by the lower end of this range.

55. Urgenda (n 8) [7.2.1]-[7.2.3].

56. Ibid [7.2.11].

57. Ibid [7.5.1].

58. In relation to the first instance decision see Jolene Lin, 'The First Successful Climate Negligence Case: A Comment on Urgenda Foundation v. The State of the Netherlands (Ministry of Infrastructure and the Environment)' (2015) 5(1) Climate Law 65; Josephine van Zeben, 'Establishing a Governmental Duty of Care for Climate Change Mitigation: Will Urgenda Turn the Tide?' (2015) 4(2) Transnational Environmental Law 339; K J De Graaf and J H Jans, 'The Urgenda Decision: Netherlands Liable for Role in Causing Dangerous Global Climate Change' (2015) 27(3) Journal of Environmental Law 517; Patrícia G Ferreira, "Common But Differentiated Responsibilities" in the National Courts: Lessons from Urgenda v. The Netherlands' (2016) 5(2) Transnational Environmental Law 329. In relation to the decision of the Dutch Court of Appeal which was upheld by the Supreme Court see Benoit Mayer, 'The State of the Netherlands v. Urgenda Foundation: Ruling of the Court of Appeal of the Hague (9 October 2018)' (2019) 8(1) Transnational Environmental Law 167.

59. Ferreira (n 58) 349.

60. Yann Robiou du Pont and Malte Meinshausen, 'Warming Assessment of the Bottom-up Paris Agreement Emissions Pledges' (2018) 9 Nature Communications 1, 2. See also Mayer (n 58) 187.

61. Bård Lahn and Göran Sundqvist, 'Science as a "Fixed Point"? Quantification and Boundary Objects in International Climate Politics' (2017) 67 Environmental Science and Policy 8, 12. 


\subsection{The need for a solution to the fair share question in climate change litigation}

It is clear from the above overview of domestic climate change cases that the manner in which domestic courts have engaged with the fair share question has undermined the ability of domestic litigation to produce results which are collectively consistent with the $1.5^{\circ} \mathrm{C}$ target. It is also clear that domestic courts' understanding of the applicable international obligations relating to climate change mitigation has had a significant bearing on the outcome of these cases. ${ }^{62}$ This is true, in particular, in relation to how domestic courts in European countries have interpreted the relevant obligations under the ECHR. Against this background, the analysis now turns to outline how, notwithstanding the absence of an agreed approach to sharing the global burden of mitigating climate change, States' IHRL obligations to prevent harm from climate change ought to be interpreted in a way that requires mitigation efforts which are collectively capable of achieving the $1.5^{\circ} \mathrm{C}$ target; particular focus will be placed on the obligations under the ECHR. ${ }^{63}$ While an overview of the relevant ECtHR jurisprudence will be provided later in the analysis, it is important to note the following at this juncture: Firstly, the principles of proportionality (in the sense that a State must not be subject to an 'impossible or disproportionate burden' $)^{64}$ and reasonableness which underpin the ECtHR's jurisprudence on positive obligations are, in relation to the obligation to prevent harm from climate change, capable of being informed by the (ill-defined) burden-sharing principles in the Paris Agreement. ${ }^{65}$ At the same time, as will be further discussed below, according to the principle of consensus referred to in Urgenda, the ECtHR could not determine the 'correct' approach to global burden-sharing in the absence of consensus on this issue. The remainder of this paper is therefore concerned with how, in these circumstances, the IHRL-based obligations to prevent harm from climate change can and should be approached in a way that minimises the risk of the type of collective outcome to which the domestic decisions considered above are inclined to contribute. The analysis commences with consideration of the recently completed Guiding Principles on Shared Responsibility.

62. For an overview of the role of international law before domestic courts in the context of an analysis of climate change litigation see Ferreira (n 58) 332-334.

63. On positive obligations under the ECHR generally see Dmitri Xenos, The Positive Obligations of the State Under the European Convention on Human Rights (Routledge, Abingdon 2012); Laurens Lavrysen, Human Rights in a Positive State: Rethinking the Relationship Between Positive and Negative Obligations in the European Convention on Human Rights (Intersentia, Cambridge 2016). On the role of human rights obligations in relation to climate change see Stephen Humphreys (ed), Human Rights and Climate Change (CUP, Cambridge 2009); Sumudu Atapattu, Human Rights Approaches to Climate Change: Challenges and Opportunities (Routledge, Abingdon 2016); Duyck et al (n 11); Alan Boyle, 'Climate Change, the Paris Agreement and Human Rights' (2018) 67 International and Comparative Law Quarterly 759; Margaretha Wewerinke-Singh, State Responsibility, Climate Change and Human Rights Under International Law (Hart Publishing, Oxford 2019); Report of the Special Rapporteur on the issue of human rights obligations relating to the enjoyment of a safe, clean, healthy and sustainable environment, 'Human Rights Obligations Relating to the Enjoyment of a Safe, Clean, Healthy and Sustainable Environment' (2019) UN Doc A/74/161.

64. Kolyadenko (n 32) [160]; Budayeva (n 44) [135].

65. Wewerinke-Singh (n 63) 110. 


\section{THE GUIDING PRINCIPLES AND THE IHRL OBLIGATION TO PREVENT HARM FROM CLIMATE CHANGE}

The Guiding Principles on Shared Responsibility, together with their commentaries, were developed by a group of international lawyers with recognised expertise in the field of international responsibility to provide guidance in relation to questions of shared responsibility of States and international organisations. ${ }^{66}$ They are of an interpretive nature and build on the existing rules of the law of international responsibility that address situations of shared responsibility. ${ }^{67}$ According to Principle 2 of the Guiding Principles on Shared Responsibility, '[t]he commission by multiple international persons of one or more internationally wrongful acts that contribute to an indivisible injury entails shared responsibility'. Thus, as the commentary to that Principle notes, ' $[\mathrm{t}] \mathrm{he}$ defining feature of shared responsibility is that multiple international persons, by committing one or more internationally wrongful acts, contribute to an indivisible injury'. 'Injury' is defined to mean 'material and non-material damage, [but] does not include legal injury', ${ }^{68}$ that is, the 'injury inherent in a breach of international law'. ${ }^{69}$ With regard to the concept of an 'indivisible injury', the commentary to Principle 2 states: 'An injury is divisible when contributions to that injury can be distinguished from each other by using a factual test of causation. This will be the case when an internationally wrongful act qualifies as the single necessary and sufficient cause of a certain injury'. ${ }^{70}$ It is clear, therefore, that for the purpose of the Guiding Principles on Shared Responsibility, harm caused by climate change constitutes indivisible injury. ${ }^{71}$

A distinction which is central to the Guiding Principles on Shared Responsibility is that which exists between shared responsibility arising from a single internationally wrongful act and shared responsibility arising from multiple internationally wrongful acts. According to Principle 3:

International persons share responsibility for a single internationally wrongful act when the same conduct consisting of an action or omission: (a) is attributable to multiple international persons; and (b) constitutes a breach of an international obligation for each of those international persons; and (c) contributes to the indivisible injury of another person.

66. André Nollkaemper et al (n 10).

67. Ibid. The introduction to the commentary states that the Guiding Principles 'expand on those rules [of the law of international responsibility] based on the practice of states and international organizations, and by relying on subsidiary means for the determination of rules of law, such as authoritative scholarly studies and decisions by international and domestic courts and tribunals'.

68. Ibid principle $1(\mathrm{c})$.

69. Ibid commentary to principle 1 , para 4 .

70. Ibid commentary to principle 2, para 4 .

71. For literature on the application of principles of shared responsibility to climate change see Roda Verheyen, Climate Change Damage and International Law: Prevention Duties and State Responsibility (Martinus Nijhoff, Leiden 2005) 268-278; Michael Faure and André Nollkaemper, 'International Liability as an Instrument to Prevent and Compensate for Climate Change' (2007) 26 Stanford Environmental Law Journal 123; Jacqueline Peel, 'Climate Change' in André Nollkaemper, Ilias Plakokefalos and Jessica N M Schechinger, The Practice of Shared Responsibility in International Law (CUP, Cambridge 2017) 1009; Heta Heiskanen, 'Climate Change and the European Court of Human Rights' in Duyck et al (n 11) 319; WewerinkeSingh (n 63) 92-96. 
This Principle reflects Article 47 of the ILC's ARSIWA which provides, in part, that '[w]here several States are responsible for the same internationally wrongful act, the responsibility of each State may be invoked in relation to that act'. ${ }^{72}$ The commentary to Principle 3, regarding shared responsibility for a single internationally wrongful act, cites the explanation in the ILC's commentary on Article 47 that a 'single wrongful act' arises when two or more international persons engage in 'a single course of conduct [which] is at the same time attributable to several [international persons] and is internationally wrongful for each of them'. ${ }^{73}$ Principle 4 , on the other hand, provides that:

International persons share responsibility for multiple internationally wrongful acts when each of them engages in separate conduct consisting of an action or omission that: (a) is attributable to each of them separately; and (b) constitutes a breach of an international obligation for each of those international persons; and (c) contributes to the indivisible injury of another person.

\subsection{Contributions to climate change as a single composite act?}

In relation to Principle 3, the commentary notes, citing Article 15 of the ILC's ARSIWA, that a single wrongful act may "consist of a composite act, which is "a series of actions or omissions defined in aggregate as wrongful"". ${ }^{74}$ Taking the ILC's example of genocide in its commentary to Article 15, it further notes: 'the act of genocide concerns some aggregate conduct and not individual acts as such. Genocide is not committed "until there has been an accumulation of acts of killing, causing harm, etc., committed with the relevant intent", which might be committed by a plurality of international persons' ${ }^{75}$ It warns, however, that 'this does not mean that an act or omission of an international person that is per se lawful would be rendered unlawful on account of it having been aggregated with other acts and omissions attributable to other international persons' ${ }^{76}$ In support of this position, the commentary to Principle 3 cites Andrea Gattini's view that 'it is inconceivable that, through the concept of a composite act, a state could be made responsible only for the fact that an act or omission which is attributable to it, and which is per se perfectly lawful, is in a way causally linked to other wrongful acts or omissions attributable to other states' ${ }^{77}$ A corresponding observation is made in the commentary to Principle 4, which notes:

A course of conduct that is lawful as such cannot engage the responsibility of the author of the act on account of the fact that, in combination with the wrongful conduct of other international persons, it contributes to the injury of a third person. For instance, in order to establish shared responsibility for the indivisible injury of climate change, violations of applicable international obligations incumbent on each of the responsible international persons need to

72. ARSIWA (n 46) 124.

73. Nollkaemper et al (n 10) commentary to principle 3, para 1 citing the ILC commentary to art 47 of the ARSIWA.

74. Ibid commentary to principle 3 , para 8 .

75. Ibid citing ILC commentary to art 15 of the ARSIWA.

76. Ibid.

77. Andrea Gattini, 'Breach of International Obligations' in André Nollkaemper and Ilias Plakokefalos (eds), Principles of Shared Responsibility in International Law: An Appraisal of the State of the Art (CUP, Cambridge 2014) 49. 
be established, for instance under international environmental law or international human rights law. ${ }^{78}$

Clearly, the authors of the Guiding Principles on Shared Responsibility take the view that an IHRL obligation to prevent harm from climate change could not be breached by multiple States in such a way as to give rise to a single composite wrongful act. It is, nevertheless, worth comparing this obligation with the example of genocide provided in the commentary. To do so, we must first consider whether a breach of an IHRL obligation can fall within Article 15 of the ARSIWA. The ILC's commentary thereon states that '[c]omposite acts covered by article 15 are limited to breaches of obligations which concern some aggregate of conduct and not individual acts as such' ${ }^{79}$ It further states that '[i]t is necessary to distinguish composite obligations from simple obligations breached by a "composite" act" ${ }^{80}$ In the case of the former, 'the obligation itself is defined in terms of the cumulative character of the conduct, i.e. where the cumulative conduct constitutes the essence of the wrongful act'. ${ }^{81}$ While IHRL obligations are not expressly defined as either composite or simple obligations, it would seem they are capable of functioning as either type of obligation. Indeed, the ECtHR has referred to Article 15 in several of its judgments. ${ }^{82}$ Given the cumulative manner in which contributions to climate change are made, and the way in which those contributions progressively intensify climate change and the harm it causes, an IHRL obligation to prevent harm caused by climate change will inevitably be concerned with 'a series of actions or omissions' extending over a significant period of time. ${ }^{83}$

How, then, does the example of the crime of genocide provided in the commentary to Principle 3 compare with an IHRL-based obligation to prevent harm from climate change? In answering this question, it is worth firstly noting a further point made by Gattini in his analysis from which the above quote is drawn. There he states:

It may well be the case that the genocide is composed of different acts attributed to different states, but it is also clear that each course of conduct constitutes a wrongful act per se. ... [I]n order to be qualified as constituting part of a genocide, each single act must be committed with the relevant intent, given the requirement of dolus specialis in the definition of genocide. $^{84}$

Therefore it seems that, according to Gattini, a single wrongful composite act of genocide can be composed of the conduct of more than one State on the basis either that: (a) the conduct of each State constitutes a wrongful act short of genocide; or

78. Nollkaemper et al (n 10) commentary to principle 4, para 3. The decision in Urgenda is cited in support of this view. It is worth recalling that the Dutch Supreme Court cited art 47 of the ARSIWA in support of its ultimate conclusion, indicating that it viewed the concept of a single internationally wrongful act as relevant to the assessment of whether States' contributions to climate change breach the ECHR.

79. ARSIWA (n 46) 62.

80. Ibid.

81. Ibid 63 .

82. See eg El Masri $v$ The Former Yugoslav Republic of Macedonia App No 39630/09 (ECtHR, 8 October 2010) [97]; Ilascu and Others v Moldova and Russia App No 48787/99 (ECtHR, 8 July 2004) [321]; Husayn (Abu Zubaydah) v Poland App No 7511/13 (ECtHR, 24 July 2014) [201].

83. Wewerinke-Singh has noted the applicability of art 15 in the context of the application of human rights obligations to climate change: see Wewerinke-Singh (n 63) 91-92, citing Verheyen (n 71) 236.

84. Gattini (n 77) 49. 
(b) the conduct of each State satisfies the mental element of the crime but falls short of the threshold level of deaths etc needed to establish the actus reus and, further, that that threshold level is only met when those deaths are aggregated together. ${ }^{85}$ In the case of 'interpretation (a)', the ILC's commentary to Article 15 refers to the 'possibility that every single act in the series could be wrongful in accordance with another obligation' but makes no suggestion that this is necessary to engage that Article. ${ }^{86}$ That leaves the IHRL obligation to prevent harm from climate change to be compared with interpretation (b)' and here there is a significant similarity between the example of genocide and the situation of climate change. In the genocide example, each State has not, by itself, met the threshold for the actus reus to render it independently liable. In the case of climate change, owing to the ambiguity around a State's fair share, there is an uncertainty as to whether an individual State has met the requisite threshold to render it independently liable for breaching its IHRL obligation to prevent harm from climate change. Furthermore, in light of that obligation, it can hardly be said that the contribution by a State to global emissions is 'per se perfectly lawful' or inherently lawful conduct.

It is worth also noting in this context the approach adopted by Judge Simma in his Separate Opinion in the Oil Platforms case before the International Court of Justice (ICJ) between Iran and the United States (US). ${ }^{87}$ That case involved a claim by the latter that a series of attacks allegedly committed by Iran, in the context of the Iran-Iraq war, against US vessels amounted to a breach of a bilateral treaty between the two parties, specifically, a provision thereof which provided for the 'freedom of commerce and navigation between [their] territories' ${ }^{88}$ The US argued that the cumulation of attacks, mine-laying and other military action by Iran, and the effect it had on its vessels, breached this obligation. ${ }^{89}$ The ICJ found that there was no such breach because no commerce between the territories of the US and Iran was undermined. ${ }^{90}$ Judge Simma dissented on this point and then proceeded to address the question of Iran's responsibility in circumstances where there was uncertainty as to which specific acts out of the cumulation of acts in question were attributable to Iran and which were attributable to Iraq. ${ }^{91}$ In doing so, he relied in part on Article 47 and stated:

[T] he 'internationally wrongful act' is constituted by the creation of negative economic, political and safety conditions in the Gulf rather than by a specific incident. The bringing about of this environment, taken as a whole, is attributable to both [Iran and Iraq], as it is common knowledge that they both participated in the worsening of the conditions prevailing in the Gulf at the time. ${ }^{92}$

85. Insofar as the ILC's commentary to art 15 of the ARSIWA proceeds on the assumption that such a threshold needs to be met to establish genocide, it will be assumed for the purpose of this analysis that this is the case. Notably, however, this view is not consistent with authority. See William Schabas, Genocide in International Law: The Crime of Crimes (2nd edn, CUP, Cambridge 2009) 179.

86. ARSIWA (n 46) 63 (emphasis added).

87. Oil Platforms (Islamic Republic of Iran v United States of America) (Judgment) [2003] ICJ Rep 161 (Oil Platforms).

88. Treaty of Amity, Economic Relations, and Consular Rights Between the United States of America and Iran (adopted 15 August 1955, entered into force 16 June 1957) 284 UNTS 93.

89. Oil Platforms (n 87) 217.

90. Ibid 217-218.

91. Oil Platforms (Separate Opinion of Bruno Simma) 353.

92. Ibid 359. 
He further held that '[i]t is the creation of dangerous conditions for shipping and doing commerce in the Gulf which constitutes the internationally wrongful act within the meaning of Article 47' which entitled the US to 'invoke the responsibility of either State, that is, also of Iran, individually'. ${ }^{93}$

There is a clear difficulty with the suggestion that the responsibility of Iraq, despite it not being a party to the treaty in question, could be invoked pursuant to Article 47. Putting this issue aside, however, Judge Simma's analysis is noteworthy because it is based on the view that a single wrongful act can be composed of conduct attributable to more than one State. According to Margaretha Wewerinke-Singh, '[a]lthough Simma did not say so, it is clear from his opinion that he considered that th[e] treaty provision [in question] could be breached through a pattern of conduct (ie what Article 15 of the [ARSIWA] calls a "composite act")' ${ }^{94}$ She goes on to conclude that Judge Simma was implicitly applying Article 15 only to the actions of Iran, ${ }^{95}$ however this view is not compatible with the manner in which he applied Article 47. Rather, it is clear from the passage quoted above that he (implicitly) considered the conduct of both Iran and Iraq to give rise to a single composite act. He used this concept to circumvent the difficulty created by the uncertainty surrounding whether specific actions which combined to create the hostile environment in the Gulf were attributable to either State. As further discussed in Section 4 below, there is a clear comparison to be drawn between the uncertainty with which Judge Simma was concerned and the uncertainty created by the fair share question in the context of climate change - both stem from the involvement of more than one State in contributing to a particular outcome. The application of Judge Simma's approach to the situation of climate change would involve addressing the uncertainty created by the fair share question by aggregating States' respective contributions to global emissions into one single act.

In the final analysis, however, it is important to emphasise that whether or not a plurality of States can be responsible for the same internationally wrongful act 'will depend on the particular primary obligation' in question. ${ }^{96}$ The view of the authors of the Guiding Principles on Shared Responsibility that the IHRL obligation to prevent harm from climate change cannot be breached by a plurality of States in such a way as to give rise to a single composite wrongful act is evidently based on the view that, owing to their nature, IHRL obligations are not capable of being breached in this way. This is undoubtedly a fair conclusion: the principles of reasonableness and proportionality that are central to the definition of States' positive obligations under IHRL are not easily reconcilable with the aggregation of State conduct into one single composite act. It remains the case, however, that there is a significant similarity between, on the one hand, both the 'threshold issue' that arises in the genocide example and the uncertainty that arose in Oil Platforms (both stemming from the involvement of more than one State) and, on the other hand, the fair share question which arises in the context of climate change. The fact that a solution could be found to the former issues via the concept of a composite act highlights the need for a solution with similar effect to the fair share question. The analysis which follows sets out how the fair share question ought to be addressed in the context of the IHRL obligation to prevent harm from climate change, in accordance with Principle 4 of the Guiding Principles on Shared Responsibility.

93. Ibid.

94. Wewerinke-Singh (n 63) 95.

95. Ibid.

96. ARSIWA (n 46) 125. 


\section{ADDRESSING THE FAIR SHARE QUESTION BY REFERENCE TO GENERAL PRINCIPLES OF DOMESTIC TORT LAW}

In his Separate Opinion in the Oil Platforms case, Judge Simma also drew on the concept of a general principle of law (for the purpose of Article 38(1) of the Statute of the ICJ) to address the ambiguity as to the extent to which Iran or Iraq's actions were responsible for creating the conditions in the Gulf that were alleged to have infringed the treaty provision at issue in that case. To this end, he reviewed the law on multiple tortfeasors in various domestic jurisdictions and found that each jurisdiction favoured the view that where multiple wrongdoers might possibly have caused a single harm but only one of them could in fact have caused that harm, each wrongdoer is at least presumptively responsible in law for the entire harm. ${ }^{97}$ As part of this comparative analysis he considered the well-known decision of the Supreme Court of California in the case of Summers $v$ Tice.$^{98}$ In that case the plaintiff had endured two separate injuries as a result of separate gunshots fired by each of the two defendants but it was not possible to determine which of them caused which injury. The court held that in such circumstances it was appropriate to place the onus on each defendant to prove that he did not cause either injury, and because they could not do so they were each held fully liable for both injuries. In relation to this decision, Judge Simma noted that while 'it excludes as unfair a solution in which no one would be held responsible', it also 'provides the wrongdoer a way out' by affording him the opportunity to prove he did not cause any harm. ${ }^{99}$

Turning to the dispute before him, he held that '[e]levating the joint-and-several liability doctrine thus described to the level of international law in the present case would lead to a finding that Iran is responsible for damages, or impediments, that it did not directly cause'. ${ }^{100} \mathrm{He}$ emphasised, however, that 'the question before us is whether Iran can be found in breach of its treaty obligations or not; in the present context I do not discuss any question of reparation'. ${ }^{101}$ With regard to the 'now theoretical' question of reparation, he found "very pertinent the compromise course steered in the Sindell v. Abbott Laboratories case' ${ }^{102}$ (a further decision of the Supreme Court of California) in which some of the potential defendants were not parties to the proceedings. ${ }^{103}$ As Judge Simma noted, in that case:

[T] he court, following Summers $v$. Tice, held each of the defendants responsible and attempted, to the best it could, to approximate each defendant's responsibility. The compromise found by the court to account for the absence of interested parties was to hold the defendants liable only for part of the damage suffered by plaintiff, not for its entirety. ${ }^{104}$

He then concluded that 'the principle of joint-and-several responsibility common to the jurisdictions that I have considered can properly be regarded as a "general principle of law" within the meaning of Article 38, paragraph 1(c), of the Court's Statute'. ${ }^{105}$ Furthermore, 'this principle should have been applied in our present case to the effect

97. Oil Platforms (Separate Opinion of Bruno Simma) (n 91) 354-358.

98. Summers v Tice, 33 Cal. 2d 80 (1948).

99. Oil Platforms (Separate Opinion of Bruno Simma) (n 91) 355.

100. Ibid 357.

101. Ibid 357-358.

102. Sindell v Abbott Laboratories, 607 P.2d 924 (1980).

103. Oil Platforms (Separate Opinion of Bruno Simma) (n 91) 358.

104. Ibid.

105. Ibid. 
that, even though responsibility for the impediment caused to United States commerce with Iran cannot ... be apportioned between Iran and Iraq, Iran should nevertheless have been held in breach of its treaty obligations'. ${ }^{106}$

Judge Simma's conclusion that joint and several liability is a general principle of international law has been the subject of criticism. Roger Alford, for example, notes that many countries as well as states in the US prefer a regime of proportional liability in situations where multiple tortfeasors do not act in concert. ${ }^{107}$ According to him ' $[\mathrm{t}$ ]hese disparate approaches suggest that there is no settled standard for apportioning liability for independent acts of multiple tortfeasors'. ${ }^{108}$ Pierre D'Argent has further argued in response to the suggestion that joint and several liability operates in international law that:

[T] he international community has not been very preoccupied with the fate of victims of wrongful acts, so that the need for a protective mechanism by which a full claim of reparation can be addressed to any of the wrongdoers is not as pressing as it has been in domestic legal orders. ${ }^{109}$

Furthermore, the absence of a system of compulsory jurisdiction in international law, which would undermine the ability of one joint-and-severally liable State to recover a contribution from another, could, if such a basis of liability existed at the international level, 'result in creating real injustices in the pursuit of justice'. ${ }^{110}$

It is worth recalling in response to these criticisms that Judge Simma was concerned not with the question of apportionment of liability for the purpose of reparations but the logically antecedent 'problems of attribution and causality posed by the existence of several tortfeasors'. ${ }^{111}$ Alford's and D'Argent's criticisms are, however, clearly directed at the reparational consequences of joint-and-several liability. Granted, that term may well be widely understood as meaning that each of those so liable is obliged to compensate the victim for the full amount of the harm caused and it is therefore understandable that they saw fit to focus their criticism on this aspect of the principle. Nevertheless, it is clear from Judge Simma's analysis that he was concerned instead with the manner in which the principles of law he reviewed operate to ensure, in a situation where it is not possible to establish which of two or more wrongdoers was causally responsible for a particular harm, that this should not act as a bar to

106. Ibid.

107. Roger P Alford, 'Apportioning Responsibility Among Joint Tortfeasors for International Law Violations' (2011) 38 Pepperdine Law Review 233, 242-244.

108. Ibid 244.

109. Pierre D'Argent, 'Reparation, Cessation, Assurances and Guarantees of Non-Repetition', in André Nollkaemper and Ilias Plakokefalos (eds), Principles of Shared Responsibility in International Law: An Appraisal of the State of the Art (CUP, Cambridge 2014) 246.

110. Ibid. For a similar example of an argument against the existence of joint and several liability in international law see Stephan Wittich 'Joint Tortfeasors in Investment Law' in Christina Binder, August Reinisch, Ursula Kriebaum et al (eds), International Investment Law for the 21st Century: Essays in Honour of Christoph Schreuer (OUP, Oxford 2009) 708, 712-722. For an argument in favour of such a basis of liability in international law see John E Noyes and Brian D Smith, 'State Responsibility and the Principle of Joint and Several Liability' (1988) 13 Yale Journal of International Law 225; Verheyen (n 71) 268-279. For a general overview of the law in this area see James Crawford, State Responsibility: The General Part (CUP, Cambridge 2013) 325-361. See also André Nollkaemper et al (n 10) discussing principle 10 of the Guiding Principles on State Responsibility and the commentary thereon.

111. Oil Platforms (Separate Opinion of Bruno Simma) (n 91) 324. 
establishing liability per se (and not with its reparational consequences). It is also clear from his endorsement of the approach taken in the Sindell case, and his reference to this case as having followed Summers $v$ Tice, that whether in such a situation liability is apportioned, according to the tort law of a particular jurisdiction, on a proportional basis or on a joint and several basis is immaterial to the existence of the general principle of law with which he was concerned. Notably, Judge Simma's critics have not challenged the manner in which he addressed, by reference to domestic tort law, the related issues of attribution and causality. Thus, insofar as there would appear to be a consensus that, where it is not possible to establish which of two or more wrongdoers caused a particular harm, this should not act as a bar to establishing liability per se, Judge Simma's conclusion that this principle rises to a general principle of law appears to be sound. ${ }^{112}$

\subsection{Applying the relevant principles of domestic tort law to the fair share question}

Why ought the principles applicable in cases involving causal uncertainty and multiple wrongdoers apply in relation to the fair share question? The first reason is that there exists a fundamental similarity between what is at issue in both types of situation. As in cases involving causal uncertainty and multiple wrongdoers, the fair share question concerns ambiguity as to the extent, if any, of the unlawful contribution to a harm caused by multiple potential wrongdoers. If any, because if a State's contribution to global emissions falls within its (undefined) fair share, then its contribution is not unlawful. In addition, in both situations the ambiguity results solely from the fact that there are multiple potential contributors. A further justification stems from the fact that the ambiguity surrounding the nature of a State's fair share is a direct consequence of the failure by States to agree on a globally applicable approach to sharing the burden of mitigating climate change. Here it is worth noting the policy argument which lies behind the principles applicable in cases involving causal uncertainty and multiple wrongdoers, as made clear in the leading English authority in this area, Fairchild $v$ Glenhaven Funeral Services. ${ }^{113}$ In that case, the plaintiffs could not establish which of several periods of exposure to asbestos by their multiple negligent employers had caused their resulting injuries. The House of Lords concluded that it

112. See Cees van Dam, European Tort Law (OUP, Oxford 2013) 329-334 (reviewing the relevant principles of tort law in Germany, France, England and the Netherlands); Christian Von Bar, The Common European Law of Torts: The Core Areas of Tort Law, its Approximation in Europe, and its Accommodation in the Legal System, vol 1 (Clarendon Press, Oxford 1998) 340-342 (reviewing the relevant principles of tort law in England, Ireland and the Scandinavian countries); Walter van Gerven, Jeremy F Lever and Pierre Larouche, Cases, Materials and Text on National, Supranational and International Tort Law (Hart, Oxford 2000) 441, 465 (reviewing the relevant principles of tort law in France, Germany and the Netherlands). See also Fairchild v Glenhaven Funeral Services Ltd and Others [2002] UKHL 22, [2003] 1 AC 32 [58]-[66] where Lord Bingham surveys the approaches in multiple jurisdictions (references were made to the laws of Germany, France, Greece, Austria, the Netherlands, Spain, California, Canada, Norway, Austria, South Africa, Italy and Switzerland), following which he concluded that 'most of the jurisdictions' support a relaxation of the rules on causation in situations involving causal uncertainty and multiple wrongdoers.

113. Fairchild (n 112). 
was sufficient in such cases for a plaintiff to establish that the defendants had merely materially increased the risk of the harm in question occurring. ${ }^{114}$ In support of this conclusion, Lord Bingham held that there was 'a strong policy argument in favour of compensating those who have suffered grave harm, at the expense of their employers who owed them a duty to protect them against that very harm and failed to do so'. ${ }^{115}$ Thus, the potential injustice entailed by relaxing the approach on causation in such a case, ie of imposing liability on a negligent defendant who had not caused the harm in question, was 'heavily outweighed by the injustice of denying redress to a victim' ${ }^{116}$ By the same token, it is on balance surely more appropriate that States, and not the victims of the harm which they collectively cause, should bear the consequences of their failure to agree on an approach to distributing amongst themselves the global burden of mitigating climate change.

How, then, do the above principles apply to the fair share question when it comes to establishing a breach of the IHRL obligation to prevent harm from climate change? On the basis of the current trajectory of climate change, the application of these principles to the fair share question requires that all States' mitigation efforts be presumed, as a starting point, to entail ongoing emissions which exceed their respective 'fair shares' the greater the extent to which climate change is on course to exceed the $1.5^{\circ} \mathrm{C}$ target, the stronger this presumption. This means that the onus must fall on the State to justify the adequacy of its mitigation efforts, with the default position being that its mitigation efforts are not 'reasonable'. Furthermore, given the fact that climate change is currently on course to vastly exceed the $1.5^{\circ} \mathrm{C}$ target, any doubt as to the adequacy of a State's mitigation efforts must result in that default position being maintained. In this regard, it follows from the principles applicable in cases involving causal uncertainty and multiple wrongdoers that ambiguities in the relevant Paris Agreement burden-sharing principles (ie those of 'common but differentiated responsibilities and respective capabilities, in the light of different national circumstances' and the related principle of equity) must be resolved in favour of a victim of climate change. This is because, when it comes to ambiguity as to the meaning of a principle, the equivalent of a presumption of fact in favour of a particular party (as applies in cases of causal uncertainty and multiple wrongdoers) is a rule which requires that ambiguity be resolved in this manner. ${ }^{117}$ In practice, this justifies greater emphasis being placed, when assessing a State's justification for the reasonableness of its mitigation efforts, on less favourable (from the perspective of the State) approaches to measuring that State's fair share. This means that greater weight must be put on measures of a State's fair share relating to, for example, its capacity to reduce emissions where

114. Ibid 68 .

115. Ibid 67.

116. Ibid.

117. The relationship between a presumption of fact, and a rule of construction which requires that ambiguity as to the meaning of a particular principle be resolved in a certain way, is illustrated by the presumption of constitutionality which operates in jurisdictions such as Ireland and Canada. This presumption determines how the onus of proof ought to apply in relation to questions of fact of relevance to the constitutionality of a particular piece of statute. It also requires that ambiguity as to the meaning of a statutory provision be resolved so as to avoid such a provision being given an unconstitutional interpretation. See Gerard W Hogan, Gerry Whyte, David Kenny et al, Kelly: The Irish Constitution (5th edn, Bloomsbury, New York 2018) para 6.2.199 and, in the Canadian context, see Joseph Eliot Magnet, 'The Presumption of Constitutionality' (1980) 18(1) Osgoode Hall Law Journal 87. 
that State has a greater capacity to do so. Importantly, the expectation in the Paris Agreement that developed countries take the lead in the area of mitigation justifies the application of this approach with greater force to such countries.

A key feature of this approach is that it does not require the identification of the 'right' measure for global burden-sharing. Nor does it involve the possibility of establishing breach simply because a State makes (or has made) any contribution to global emissions; in Judge Simma's language, States still have a 'way out'. But, crucially, this approach significantly limits the risk of States being able to 'extricate' themselves from the presumptive responsibility which they entail on the basis of mitigation efforts which are collectively incapable of keeping climate change to the $1.5^{\circ} \mathrm{C}$ target. In this way, this approach is consistent with, and provides a normative basis for relying on, the approach taken by the Climate Action Tracker (CAT) ('an independent scientific analysis that tracks government climate action and measures it against the globally agreed Paris Agreement' $)^{118}$ to assessing the fairness of a State's mitigation efforts. The CAT's approach is to construct a 'fair share range' from the wide range of approaches to measuring the fairness of a particular State's mitigation efforts. ${ }^{119}$ That range is then divided into three sections: 'insufficient', ' $1.5^{\circ} \mathrm{C}$ compatible' and ' $2{ }^{\circ} \mathrm{C}$ compatible'. Each section corresponds to the temperature outcome that would result if all other countries were to adopt mitigation efforts of equivalent ambition relative to their respective fair share ranges. This means that only where a State's mitigation efforts are compatible with the relatively more demanding measures of fairness within its fair share range will those efforts be rated as compatible with the $1.5^{\circ} \mathrm{C}$ target. Notably, none of the Member States of the Council of Europe (the Member States of the EU are rated collectively) achieve a CAT rating greater than 'insufficient'. ${ }^{120}$

\subsection{The proposed approach to the fair share question and the ECHR}

To what extent, then, ought this approach to addressing the fair share question (the proposed approach) apply to the interpretation of the positive obligation to prevent harm from climate change under the ECHR? Here, a number of principles relating to the interpretation of the Convention are of note. Firstly, it is well established that the Convention must be interpreted in a manner that is 'most appropriate in order to realise the aim and achieve the object of the treaty', ${ }^{121}$ that being the 'protection of individual human beings'. ${ }^{122}$ Furthermore, the obligations under the Convention must be interpreted in a way that ensures that the rights enshrined therein are 'practical and effective' rather than 'theoretical and illusory'. ${ }^{123}$ More specifically, '[t]he consensus emerging from specialised international instruments and from the practice of Contracting States may constitute a relevant consideration for the Court when it

118. Climate Action Tracker, 'About' <https://climateactiontracker.org/about/> accessed 18 May 2020.

119. Climate Action Tracker, 'Comparability of Effort' < https://climateactiontracker.org/ methodology/comparability-of-effort/> accessed 18 May 2020.

120. Climate Action Tracker, 'Countries' <https://climateactiontracker.org/countries/> accessed 18 May 2020.

121. Wemhoff v Germany (1968) Series A no 7 [8].

122. Soering v United Kingdom (1989) Series A no 161 [87].

123. Airey v Ireland (1979) Series A no 33 [24]. 
interprets the provisions of the Convention in specific cases'. ${ }^{124}$ Similarly, regarding the relationship between other aspects of international law and the Convention, the ECtHR has held:

Where a number of apparently contradictory instruments are simultaneously applicable, international case-law and academic opinion endeavour to construe them in such a way as to coordinate their effects and avoid any opposition between them. Two diverging commitments must therefore be harmonised as far as possible so that they produce effects that are fully in accordance with existing law. ${ }^{125}$

A State cannot, however, dilute its obligations under the Convention by binding itself to another international agreement. ${ }^{126}$ Finally, as with international agreements, general principles of law for the purpose of Article 38(1) of the Statute of the $\operatorname{ICJ}^{127}$ and similarly, the "norms and principles applied ... in the domestic law of the majority of member States of the Council of Europe ${ }^{\prime 28}$ may also inform the interpretation of the Convention.

Applying these principles, the Paris Agreement, for a start, provides clear expression of a consensus as to the need to keep global warming to the $1.5^{\circ} \mathrm{C}$ target in order to prevent 'significant deleterious effects ... on human health and welfare'. ${ }^{129}$ At the same time, as previously noted, the absence of consensus as to the appropriate approach to burden-sharing would preclude the ECtHR from endorsing any one such approach as the 'proper' approach. According to the above principles, however, the fact that States have not bound themselves to specific reduction targets (derived from a particular approach to burden-sharing) which are collectively capable of achieving the $1.5^{\circ} \mathrm{C}$ target ought not to preclude an interpretation of States' ECHR obligations in a way that is consistent with the realisation of this target. To allow States the latitude which the Paris Agreement affords when determining their fair share of the required global mitigation effort to colour the understanding of these particular obligations would involve diluting the free-standing ECHR obligation to prevent harm from climate change by absorbing into the Convention the weaknesses of the Paris Agreement's bottom-up approach. It would equally render the right to live in an environment where climate change has not exceeded the $1.5^{\circ} \mathrm{C}$ target 'theoretical and illusory'. Instead, a harmonious interpretation of the Paris Agreement and these ECHR obligations, which is consistent with the latter's object of protecting individual human beings, must be found. The proposed approach allows for such a harmonious interpretation. Indeed, it is entirely consistent with the Paris Agreement's ultimate objective of preventing global warming from exceeding the $1.5^{\circ} \mathrm{C}$ target. Furthermore, insofar as it draws on general principles of domestic law, the role of such principles in the interpretation of the Convention provides an additional basis for its application to the ECHR obligation to mitigate climate change.

The proposed approach, based as it is on Principle 4 of the Guiding Principles on Shared Responsibility, is also consistent with what Maarten Den Heijer has identified

124. Demir and Baykara (n 52) para 85. On the role of consensus in interpreting the ECHR generally, see Council of Europe, 'European Court of Human Rights: Dialogue Between Judges' (2008); Kanstantsin Dzehtsiarou, European Consensus and the Legitimacy of the European Court of Human Rights (CUP, Cambridge 2015).

125. Nada v Switzerland App No 10593 (ECtHR, 12 September 2012) [170].

126. X v Germany App No 235/56 (ECommHR, 10 June 1958) 25.

127. Golder v United Kingdom (1975) Series A no 122 [35].

128. Demir and Baykara (n 52) [86].

129. Paris Agreement (n 2) art 2; UNFCCC (n 54) arts 1(1) and 3. 
as the typical approach of the ECtHR to situations where two States contribute to a single harmful outcome, ie the Court 'determines the responsibility of each of the contracting states individually by assessing the state's own conduct in relation to its Convention obligations'. ${ }^{130} \mathrm{He}$ further observes that:

The guiding principle that the Convention guarantees rights that are not theoretical or illusory but practical and effective ensures that states may well incur responsibility for acts of which they are not the principal author, but to which they have contributed nonetheless, such as in the cases of Rantsev [and] Ilaşcu ... ${ }^{131}$

In Rantsev $v$ Cyprus and Russia, ${ }^{132}$ which concerned the responsibility of the respondent States for the trafficking and consequent death of the applicant's daughter, the ECtHR held that States had a 'duty in cross-border trafficking cases to cooperate effectively with the relevant authorities of other States concerned in the investigation of events which occurred outside their territories'. ${ }^{133}$ Ilasscu and Others v Moldova and Russia ${ }^{134}$ concerned the responsibility of both of the respondent States in that case arising from the sentencing to death of the applicants by the Russian-supported Moldavian Republic of Transdniestria (MRT), a secessionist regime in control of the Moldovan territory of Transdniestria. The ECtHR held that a State which is faced with the establishment of a separatist regime on its territory "must endeavour, with all the legal and diplomatic means available to it vis-à-vis foreign States and international organisations, to continue to guarantee the enjoyment of the rights and freedoms defined in the Convention'. ${ }^{135}$ On this basis it found that Moldova had failed to fulfil its obligations to the applicants on account of the manner in which it had engaged in negotiations with both the MRT and Russia. ${ }^{136}$ Russia was held responsible for supporting the MRT. ${ }^{137}$ Both cases illustrate how the Court tailors the individual obligations of States in cases involving multiple contributions to a single harm to ensure that these obligations are mutually consistent with ensuring the prevention of that harm. This provides further support for the application of the proposed approach to the ECHR obligation to mitigate climate change insofar as it ensures that the mitigation efforts of States Parties to the Convention are collectively capable of contributing to the achievement of the $1.5^{\circ} \mathrm{C}$ target.

Rantsev and Ilaşcu also support the view that the emphasis placed in a number of the European domestic cases discussed in Section 2 on the discretion or 'margin of appreciation' enjoyed by governments under the ECHR when adopting mitigation measures is misguided. It is widely agreed that the margin of appreciation enjoyed by States stems primarily from the principle of subsidiarity. ${ }^{138}$ The latter principle in turn finds expression in the ECtHR's understanding that 'by reason of their direct

130. Maarten den Heijer, 'Shared Responsibility Before the European Court of Human Rights' (2013) 60(3) Netherlands International Law Review 411, 414.

131. Ibid 439.

132. Rantsev v Cyprus and Russia App No 25965/04 (ECtHR, 7 January 2010).

133. Ibid [289].

134. Ilaşcu (n 82).

135. Ibid [333].

136. Ibid [348]-[352].

137. Ibid [393].

138. See Oddný Mjöll Arnardóttir, 'Rethinking the Two Margins of Appreciation' (2016) 12 European Competition Law Review 27, 38; Steven Greer, The Margin of Appreciation: Interpretation and Discretion Under the European Convention on Human Rights (Council of Europe 2000) 34. 
and continuous contact with the vital forces of their countries, state authorities are in principle in a better position than the international judge to give an opinion on' certain matters relating to the interpretation and implementation of the Convention. ${ }^{139}$ It should follow therefore that a much narrower margin of appreciation ought to apply in situations where the protection of human rights depends on the actions of multiple States operating effectively in relation to each other. In such cases, the ECtHR, from its vantage point as an international court, is arguably best placed to determine the scope of States' obligations. This is borne out by the decisions in both Rantsev and Ilaşcu where the Court made no reference to the margin of appreciation despite addressing matters in respect of which governments would typically enjoy broad discretion, particularly in relation to the conduct of negotiations with a foreign State, as in Ilaşcu. It is also important to emphasise in this context that ' $[\mathrm{t}] \mathrm{he}$ doctrine of the margin of appreciation has always been meant as a tool to define relations between the domestic authorities and the Court [and] cannot have the same application to the relations between the organs of the State at the domestic level'. ${ }^{140}$ The emphasis in a number of the European domestic decisions considered in Section 2 on judicial restraint and related separation of powers considerations when applying the ECHR is therefore also misguided.

\section{CONCLUSION}

Human rights-based litigation has a vital role to play in the fight to prevent global warming from exceeding the $1.5^{\circ} \mathrm{C}$ target. For this form of litigation to be fully effective, however, a solution will need to be found to the problem posed by the fair share question. As demonstrated in Section 2, the potential for litigation to contribute towards the bringing about of the deep cuts in global emissions that are so urgently needed has been significantly hampered by this problem. The recently adopted Guiding Principles on Shared Responsibility considered in Section 3 provide guidance on how to address situations, such as climate change, in which multiple States contribute to 'indivisible injury'. They make clear that, to establish that a State has breached its IHRL obligation to prevent harm from climate change, it must be shown that the State in question has committed a breach of that obligation, separately from any breach committed by other States bound by the same obligation. It is, therefore, not possible to circumvent the challenge posed by the fair share question by simply aggregating the multiple contributions to climate change of States bound by the same IHRL obligations into one single internationally wrongful act. At the same time, the analysis in Section 3 regarding, in particular, how the crime of genocide can be committed by multiple States as a single wrongful act calls for a solution to the fair share problem that arises in relation to climate change. It is a moral truism that the involvement of multiple States in the intentional destruction of a national, ethnical, racial or religious group of people should provide no barrier to establishing the crime of genocide. Surely, therefore, the fair share problem, stemming as it does from the fact that climate change is a problem caused by multiple States, cannot be permitted to inhibit IHRL from effectively addressing an existential threat to humanity. Indeed, when, as the UN Special Rapporteur on extreme poverty and human rights has pointed out, 'human rights might not survive the coming upheaval' if climate change continues

139. Handyside v United Kingdom App No 5493/72 (ECtHR, 7 December 1976) [48]. 140. A and Others $v$ United Kingdom App No 3455/05 (ECtHR, 19 February 2009) [184]. 
on its current course, the very survival of IHRL itself may depend on its ability to adequately address this issue. ${ }^{141}$ As outlined in Section 4, a solution to this issue lies in the principles applied in the domestic law of multiple States to address causal ambiguity which stems from the involvement of multiple wrongdoers. They provide a basis on which to argue that, far from providing a reason for judges to take a deferential approach to assessing the adequacy of States' mitigation efforts, the ambiguity inherent in the fair share question must be resolved in favour of victims of harm. The jurisprudence of the ECtHR makes clear that these principles ought to be applied to the fair share question in the context of the ECHR obligations to prevent harm from climate change. However, as the decisions from the European jurisdictions considered in Section 2 demonstrate, clarification that this is the case will be needed from the ECtHR before domestic courts (the only courts with the tools at their disposal to force governments to adopt the necessary measures) will apply the Convention in this way. In light of the ever-narrowing window of time left to prevent climate change exceeding the $1.5^{\circ} \mathrm{C}$ target, such clarification from the ECtHR, and indeed other international bodies, is urgently needed.

141. Report of the Special Rapporteur on extreme poverty and human rights, 'Climate Change and Poverty' (2019) UN Doc A/HRC/41/39. 